University of Miami Law School University of Miami School of Law Institutional Repository

2019

\title{
Occupational Licensing and the Limits of Public Choice Theory
}

Ryan Nunn

The Hamilton Project

Gabriel Scheffler

University of Miami School of Law, gscheffler@law.miami.edu

Follow this and additional works at: https://repository.law.miami.edu/fac_articles

Part of the Antitrust and Trade Regulation Commons, and the Health Law and Policy Commons

\section{Recommended Citation}

Ryan Nunn and Gabriel Scheffler, Occupational Licensing and the Limits of Public Choice Theory, 4 Admin. L. Rev. Accord 25 (2019).

This Article is brought to you for free and open access by the Faculty and Deans at University of Miami School of Law Institutional Repository. It has been accepted for inclusion in Articles by an authorized administrator of University of Miami School of Law Institutional Repository. For more information, please contact library@law.miami.edu. 


\title{
OCGUPATIONAL LICENSING AND THE LIMITS OF PUBLIC GHOICE THEORY
}

\author{
RYAN NUNN* \& GABRIEL SCHEFFLER**
}

\begin{abstract}
Public choice theory has long been the dominant lens through which economists and other scholars have viewed occupational licensing. According to the public choice account, practitioners favor licensing because they want to reduce competition and drive up their own wages. This essay argues that the public choice account has been overstated, and that it ironically has served to distract from some of the most important harms of licensing, as well as from potential solutions. We emphasize three specific drawbacks of this account. First, it is more dismissive of legitimate threats to public health and safety than the research warrants. Second, it places disproportionate emphasis on those professions for which the justification for licensing seems weakest, rather than on those for which the justification is stronger. Third, it puts an inordinate focus on whether an occupation is licensed, rather than how it is licensed. Judges and policymakers should bear these limitations in mind when evaluating legal challenges or proposed reforms to licensing laws.
\end{abstract}

* Policy Director, The Hamilton Project; Fellow, Economic Studies, Brookings Institution.

** Regulation Fellow, Penn Program on Regulation, University of Pennsylvania Law School; Research Fellow, Solomon Center for Health Law and Policy, Yale Law School.

We thank Martha Gimbel, Clark Neily, Frank Pasquale, and Abigail Wozniak for very helpful comments on earlier drafts. Many thanks also to the editors of the ALR Accord, and in particular Brianna Gardner, for providing extremely helpful editorial assistance. 
TABLE OF GONTENTS

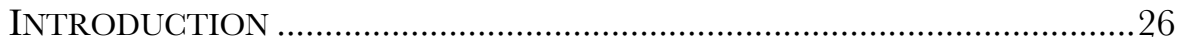

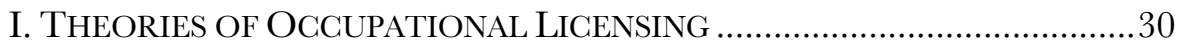

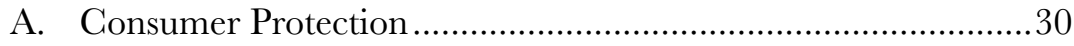

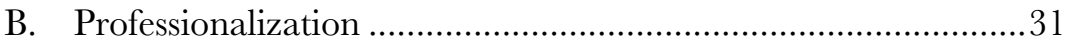

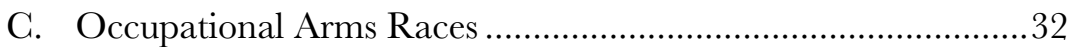

II. ThE LiMITS OF THE PUBLIC CHOICE ACCOUNT ....................................33

A. Does Licensing Improve Quality and Protect Health and

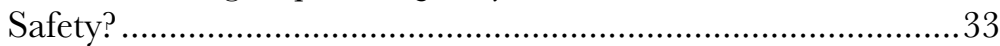

B. The Harms of Licensing in Traditionally Licensed Fields .........35

C. The Potential for Improving - Not Abolishing - Licensing .......38

\section{INTRODUCTION}

Public choice theory has long been the dominant lens through which economists and other scholars have viewed occupational licensing. ${ }^{1}$ According to the public choice account, political officials are primarily motivated by their own material self-interest, and practitioners seek licensing in order to reduce competition and drive up their own wages at the expense of the general public. ${ }^{2}$ In other words, public choice theory implies that the goal of licensing is not to improve quality or to protect public safety, but rather to reduce competition. ${ }^{3}$

The predominance of the public choice account of occupational licensing is attributable to its explanatory power: it helps to explain several features of the licensure system in the United States that are difficult to understand from any other perspective. For example, occupational licensing requirements vary tremendously from state to state, and often do not bear

1. See, e.g., Marc T. Law \& Sukkoo Kim, Specialization and Regulation: The Rise of Professionals and the Emergence of Occupational Licensing Regulation, 65 J. EcON. Hist. 723, 724 (2005) ("The dominant view today is that the regulatory licensing process has been captured by industry to erect entry restrictions for its own benefit."); Keith B. Leffler, Physician Licensure: Competition and Monopoly in American Medicine, 21 J.L. \& ECON. 165, 165 (1978) ("It is widely believed among economists that barriers to entry into medical practice have been erected for the economic advantage of those practicing medicine.").

2. See Paul J. Larkin, Jr., Public Choice Theory and Occupational Licensing, 39 Harv. J.L. \& PUB. POL'Y 209, 234 (2016) (noting that in "today's policymaking arena . . . individuals are primarily motivated by self-interest, rather than the public interest.").

3. See, e.g., Walter Gellhorn, The Abuse of Occupational Licensing, 44 U. CHI. L. REV. 6, 11 (1976) ("That restricting access is the real purpose, and not merely a side effect, of many if not most successful campaigns to institute licensing schemes can scarcely be doubted.”). 
any apparent relation to public health and safety concerns or to the specific demands of the profession. ${ }^{4}$ These discrepancies are difficult to account for if the primary purpose of licensing is to protect the public or to correct a market failure. ${ }^{5}$

Public choice theory also helps to explain why licensing laws have proliferated in recent decades. Roughly one in four workers in the United States holds an occupational license today, up from an estimated five percent in the early 1950s. ${ }^{6}$ Because the benefits of licensure primarily accrue to licensed professionals while its costs are dispersed broadly across the population, new licensing laws are much easier to pass than to repeal. ${ }^{7}$ In addition, states have an incentive to favor increasing the number of licensed professions because licensing boards are usually funded through fees and are often revenue-generating. ${ }^{8}$ For these reasons, unlike some other applications of public choice theory, the public choice account of occupational licensing has largely been accepted. ${ }^{9}$

In recent years, litigants and scholars have increasingly invoked the public choice narrative in favor of more stringent judicial review of occupational licensing and regulation more generally. ${ }^{10}$ Traditionally, courts upheld

4. See Dick M. Carpenter II et Al., License to Work: A National Study of Burdens From Occupational Licensing Inst. FOR Justice 6, 24-25 (2d ed. 2017); Larkin, supra note 2, at 219-20 ("There also appears to be no rational relationship between the stringency of the licensing requirements and the demands placed on practitioners.").

5. See Dana Berliner et al., Occupational Licensing Run Wild 11 (2017) ("П]f the public benefits from occupational licensing were obvious (and/or genuine) for any given vocation, we would expect to observe broad consensus in legal and regulatory requirements across the states, both in terms of what occupations are regulated and what credentials are required for licensure.”).

6. Bureau of Lab. Stats., 2017 Data on Certifications and Licenses, Labor Force Statistics from the Current Population Survey (2018); see also Morris M. Kleiner \& Alan B. Krueger, The Prevalence and Effects of Occupational Licensing, 48 BRIT. J. IND. ReL. 676, 677, 678 (2010); Morris Kleiner \& Alan B. Krueger, Analyzing the Extent and Influence of Occupational Licensing on the Labor Market, 31 J. LAB. EcON. S173, S175-76 (2013) (explaining the rise in occupational licensing from the 1950s to the late 2000s).

7. See generally Mancur Olson, The Logic of Collective Action: Public Goods And the Theory of Groups (1965); George Stigler, The Theory of Economic Regulation, 2 Bell J. Econ. Man. Sci. 3 (1971).

8. See Robert J. Thornton \& Edward J. Timmons, The De-Licensing of Occupations in the United States, Monthly Lab. Rev., May 2015, at 10.

9. See John Blevins, License to Uber: Using Administrative Law to Fix Occupational Licensing, 64 UCLA L. REV. 844, 868-69 (2017) ("While regulatory critics often invoke public choice too casually to oppose any regulation, the theory works well for occupational licensing.").

10. See, e.g., Brief for the Cato Institute as Amicus Curiae in Support of Petitioners at 21, Niang v. Tomblinson, 2018 WL 1785178 (2018) (No. 17-1428) ("The real motivation of the industry insiders who chiefly populate the [licensing] board here is neither public health nor consumer protection, but rather a self-serving de-sire to limit market entry by potential 
licensing schemes as constitutional as long as there was a plausible public safety rationale; ${ }^{11}$ however, several courts have recently invalidated occupational licensing arrangements on constitutional grounds. ${ }^{12}$ In doing so, some courts have echoed the standard public choice account of licensing, striking down licensing laws that - in their view - solely serve to shield practitioners from competition and to enhance their market power. ${ }^{13}$

The influence of public choice theory can be seen in a recent challenge to a Missouri cosmetology and barber licensing law. The Petitioners challenged the constitutionality of this law, arguing that "greater understanding of licensing burdens and regulatory capture require... [the Supreme] Court to revisit its occupational licensing decisions." 14 In doing so, the Petitioners further argued that the Court should overturn long-held legal prec-

competitors while collecting tens of thousands of dollars on training programs run by those same insiders."); Larkin, supra note 2, at 330-31 ("Numerous state regulatory schemes function simply as a means of limiting entry by potential rivals to protect incumbents against competition and allow them to raise the price of their services. Indeed, occupational licensing schemes often serve no other purpose... It is time for the Supreme Court to acknowledge what is actually going on with occupational licensing and to intervene to protect the public from the worst excesses of that practice."); see also Joseph Sanderson, Don't Bury the Competition: Occupational Licensing and a Toolbox for Reform, 31 YALE J. REG. 455, 465 (2014) ("Most recent occupational licensing litigation has come in the form of constitutional challenges to one scheme or another, often brought by libertarian public interest law firms seeking to reintroduce intensive scrutiny of economic regulations.").

11. See Sandra Johnson, Structure of Governmental Oversight of Quality in Healthcare, in THE Oxford HandboOK Of U.S. Health Law 492, 494 (I. Glenn Cohen et al. eds., 2017) (explaining that the state's use of its police power to regulate occupations must "further health, safety, and the general welfare," and that challenges to licensing schemes as illegitimate uses of the police power are typically unsuccessful); see, e.g., Williamson v. Lee Optical of Oklahoma, 348 U.S. 483, 487-88 (1955); Nat'l Ass'n for the Advancement of Psychoanalysis v. California Bd. of Psychology, 228 F.3d 1043, 1051-53 (9th Cir. 2000) (upholding occupational licensing schemes as constitutional).

12. See Nick Robinson, The Multiple Fustifications of Occupational Licensing, 93 WASH. L. REv. 1903, 1906 (2018) ("[O]ver the past several decades the federal courts have created a de facto occupational licensing jurisprudence through their interpretation of the first and fourteenth amendments of the Constitution as well as antitrust law... Federal courts have ... used the equal protection and due process clauses of the 14th amendment to strike down occupational licensing requirements for occupations like African hair braiders, casket sellers, and some pest control professionals."); see, e.g., Saint Joseph Abbey v. Castille, 712 F. 3d 215, 223, 226 (5th Cir. 2013) (finding no rational relationship between public health and safety and the restriction at issue).

13. See, e.g., Craigmiles v. Giles, 312 F.3d 220, 224 (6th Cir. 2002) ("Courts have repeatedly recognized that protecting a discrete interest group from economic competition is not a legitimate governmental purpose.”).

14. See Petition for Writ of Certiorari at 34, Niang v. Tomblinson, 2018 WL 1785178 (2018) (No. 17-1428); see also Brief for Public Choice Scholars as Amici Curiae Supporting Petitioners at 5-6, Niang v. Tomblinson, 2018 WL 1785178 (2018) (No. 17-1428). 
edent and hold that the Privileges or Immunities Clause guarantees the "right to pursue an economic livelihood."15 Others have discussed the dangers of reviving Lochner-style judicial review of regulation, which is outside the scope this Essay. ${ }^{16}$ Suffice it to say, such a decision would have vast implications not only for occupational licensing, but also for regulation more generally. ${ }^{17}$

This Essay argues that the public choice account of occupational licensing has been overstated, which has served to distract from some of the most important harms of licensing, as well as from potential solutions. Part I describes alternative theoretical accounts that play a role in explaining occupational licensing, including consumer protection, professionalization, and occupational "arms races."

Part II then emphasizes three particular drawbacks of the standard public choice account. First, the standard public choice account of licensing is more dismissive of legitimate threats to public health and safety than the research warrants. This is counterproductive because it provides judges and policymakers with an oversimplified framework for applying legal doctrine and implementing regulatory policy that dismisses legitimate public safety risks.

The second drawback - closely related to the first - is that overreliance on the public choice account of licensing tends to place a disproportionate emphasis on those professions for which the public interest account is least plausible (e.g., barbers), rather than on traditionally licensed professions (e.g., doctors), for which the justification for licensing is stronger. However, this view may overlook some of the most harmful consequences of licensing. By contrast, we argue that licensure reform is especially necessary for professions in fields such as health care and law, even though members of those professions may pose credible risks to health and safety.

A third related problem is that the public choice account often puts an inordinate focus on whether an occupation is licensed, rather than how it is licensed. This can blind policymakers and advocates to the ways that licensing can be reformed without simply eliminating licensure for a particular profession.

15. Petition for Writ of Certiorari, supra note 14, at 38-41 (arguing that the Supreme Court should overturn the Slaughter-House Cases). The Court ultimately did not do so, instead invalidating the law as moot. See Niang v. Carroll, 879 F.3d 870 (8th Cir. 2017), vacated as moot, Niang v. Tomblinson, 139 S. Ct. 319 (2018).

16. See, e.g., Blevins, supra note 9, at 877 (arguing that reviving Lochner would turn courts into "super-legislatures free from democratic control").

17. Id. (" $[\mathrm{A}]$ revived Lochner doctrine could easily expand beyond the occupational licensing context. The logic of these doctrines extends to other regulatory realms that impact one's economic freedom, such as labor, health, and environmental restrictions. Occupational licensing could thus validate the doctrine and make it respectable to use in other contexts. And once unleashed, the doctrines could not be checked by legislative actions."). 
We conclude by cautioning that judges and policymakers should bear the limitations of the public choice account in mind when evaluating how - and whether - to change licensing laws, and that they should avoid relying solely on the standard public choice narrative. Understanding these limitations is particularly important at this moment, given that legal advocates are attempting to bootstrap the public choice account into overturning existing legal precedent and reviving more searching judicial scrutiny of regulation. ${ }^{18}$

\section{THEORIES OF OCCUPATIONAL LICENSING}

It is simplest to see the limitations of the public choice account by examining situations in which other explanations are more compelling. To be sure, public choice mechanisms can complement these explanations, but a narrow focus on the classic Olsonian dynamic is missing other important parts of the story. ${ }^{19}$

\section{A. Consumer Protection}

The traditional legal justification for licensure is that it is necessary to protect the public from incompetent or deceptive practitioners. ${ }^{20}$ According to this view, licensing ensures quality by mandating that practitioners meet certain minimum training and educational requirements. This is especially important in certain fields where consumers have incomplete information about practitioners' competence or where practitioners can inflict serious harm on consumers. ${ }^{21}$ Depending on the nature of this informational problem, licensing or other regulatory interventions may be necessary to improve market outcomes and protect public health and safety. ${ }^{22}$

18. Id. at 871 .

19. See David Schleicher, Stuck! The Law and Economics of Residential Stagnation, 127 YALE L.J. 78, 119 (2017) ("The politics of occupational licensing follow a classic Olsonian script.").

20. See Dent v. West Virginia, 129 U.S. 114, 122 (1889) ("The power of the State to provide for the general welfare of its people authorizes it to prescribe all such regulations as in its judgment will secure or tend to secure them against the consequences of ignorance and incapacity, as well as of deception and fraud.").

21. See Kenneth J. Arrow, Uncertainty and the Welfare Economics of Medical Care, 53 AM. ECON. REv. 941, 967 (1963) (stating that the appropriate regulatory design "in any given case depends on the degree of difficulty consumers have in making the choice unaided, and on the consequences of errors of judgment").

22. See, e.g., Hayne E. Leland, Quacks, Lemons, and Licensing: A Theory of Minimum Quality Standards, 87 J. PoL. Econ. 1328, 1339, 1342-43 (1979) (arguing that a government may have an interest in imposing quality standards higher than those that would prevail in the free market). 


\section{B. Professionalization}

As public choice theorists suggest, the path to licensure generally requires that members of an occupation first become organized in order to effectively lobby a state legislature. ${ }^{23}$ However, occupations do not organize solely for the purpose of becoming licensed.

Rather, professionalization - which typically goes hand-in-hand with occupational self-organization - generates other benefits for workers and consumers. The professionalization process takes on a variety of forms, including the establishment of uniform curricula, standards, and certifications. ${ }^{24}$ Particularly when occupations deal with technologically complex problems, information about service quality is often difficult for consumers to access. ${ }^{25}$ By improving education and training and establishing strong signals of quality that give consumers more confidence in the profession, members of an occupation can benefit both themselves and the general public. ${ }^{26}$

Professionalization requires institutions that can conduct the organizational work required to establish uniform standards and processes. Professional schools, accreditation or certifying bodies, and associations are all part of this institutional apparatus. ${ }^{27}$ Once these institutions have been built, it is a much shorter step to licensure than it would otherwise have been. At this point, members of the occupation now have a professional body that represents them and a detailed, implementable plan for licensure (including required curricula).

Licensing is often viewed as the last step to raise the status of the licensed profession, though the desire to exclude competitors and raise wages in the profession - to the detriment of consumers and other workers - is likely an important part of the motivation as well. ${ }^{28}$ The key point, however, is that the other steps in the professionalization process, like establishing uniform educational and training standards, do not necessarily limit competition. ${ }^{29}$

23. See Charles J. Wheelan, Politics or Public Interest? Licensing and the Case of Respiratory Therapists, Perspectives On Work, Winter 2005, at 42-43.

24. See Dep't of the Treasury, Office of Econ. Pol'y, The Council of Econ. Advisers \& The Dep'T of Lab., Occupational Licensing: A Framework for POLICYMAKERS 11 (2015) [hereinafter WH REPORT].

25. Id.

26. Id.

27. See Paul Starr, Professionalization and Public Health: Historical Legacies, Continuing Dilemmas, 15 J. Pub. Health Mgmt. Prac. S26, S27 (2009).

28. See Benjamin Shimberg et Al., Occupational Licensing: Practices and Policies 13 (1972) ("[L]icensing is often promoted as a way to enhance the status and the public image of the group. Not so loudly heralded but certainly as important an incentive is the economic benefit that often accompanies licensure.").

29. See Starr, supra note 27, at S27 ("To be sure, the professional autonomy and status of physicians have their clear benefits and not just from the standpoint of physicians. The perquisites of medicine have served a public interest by attracting highly qualified students 


\section{Occupational Arms Races}

Occupations do not always come with tasks that are clearly distinct from those of other occupations. In many instances, there is substantial overlap, such as between physical therapists and athletic trainers, or between advanced practice registered nurses and physicians, or between dental hygienists and dentists. In a world without occupational licensing, this overlap would not pose any regulatory issues.

But when at least one occupation is licensed - with an exclusive statutory right to conduct a set of tasks - occupations with overlapping functions will also have an interest in becoming licensed. ${ }^{30}$ Members of these occupations that seek licensure are not necessarily attempting to benefit at the expense of consumers, but may simply be defending their ability to work against the earlier-licensed incumbents by organizing and obtaining a fully authorized scope of practice. ${ }^{31}$ Conversely, the earlier-licensed incumbent professionals may be attempting to maximize their earnings and employment at the expense of the less-privileged profession. ${ }^{32}$

One might argue that this is consistent with a public choice account - if that is defined broadly to encompass any self-interested behavior of the professions. However, it is inconsistent with the paradigmatic case of a single organized interest group securing rents at the expense of a dispersed group of consumers. Instead, organized interest groups are largely battling each other for access to jobs. ${ }^{33}$

Importantly, the different explanations for licensing may be difficult to disentangle and are not necessarily mutually exclusive. For example, although historians have written several treatises on the origins of medical li-

into the field and encouraging them to invest in and endure a lengthy and demanding education .... Beginning around the turn of the 20th century; however, physicians' success in using licensure and other measures to get stronger protection against competition raised the costs of healthcare.")

30. See Morris M. Kleiner, Battling over Fobs: Occupational Licensing in Health Care, 106 AM. ECON. REv. 165, 168 (2016) (describing how physical therapists are sometimes advantaged relative to occupational therapists by the terms of their occupational licensure).

31. The legal ability to carry out all the tasks for which a worker has been trained is quite important to his or her earnings and employment. For example, even in the case of marginal restrictions to their scope of practice, nurse practitioners (NPs) suffer substantial earnings reductions, balanced by earnings increases for physicians. See Morris M. Kleiner et al., Relaxing Occupational Licensing Requirements: Analyzing Wages and Prices for a Medical Service, 59 J.L. \& ECON. 261, 274-75 (2016). In addition, states with more restrictive scopes of practice have lower employment of NPs. Id.

32. See id.

33. See Kleiner, Battling over Fobs, supra note 30, at 166, 168 (2016) (arguing that more market-based systems like certification could increase equity and efficiency in the labor market). 
censure, there still is no clear historical consensus as to whether "regular" allopathic physicians initially sought licensure primarily to enhance their own market power over competing medical schools, or whether they did so to improve quality by driving out low-quality practitioners. ${ }^{34}$ Some scholars have embraced a combination of these theories. ${ }^{35}$

In Daniel Carpenter and David Moss's book on regulatory capture, they suggest that there may be a middle ground between the public choice account of regulation and the public interest view. ${ }^{36}$ Carpenter and Moss define "weak capture" as "when special interest influence compromises the capacity of regulation to enhance the public interest, but the public is still being served by regulation, relative to the baseline of no regulation." ${ }_{37}$ An economist might characterize this state of affairs in terms of average and marginal net benefits: the average net benefit of occupational regulation can still be positive even when the marginal net benefit is negative. ${ }^{38}$ It is possible, then, that even when practitioners seek licensing out of a desire to enhance their own market power or skew licensing restrictions in anticompetitive ways, there are at least some instances in which the public is still better off with some licensing than with none.

\section{The Limits OF THE Public CHOICE AGCOUNT}

\section{A. Does Licensing Improve Quality and Protect Health and Safety?}

Proponents of the public choice account sometimes point to the paucity of empirical evidence finding that licensing improves quality or public safety as support for the public choice account of licensing. ${ }^{39}$ Yet a careful review of the empirical research paints a more nuanced picture. While it is

34. See Timothy Stolzfus Jost, Oversight of the Quality of Medical Care: Regulation, Management, or the Market? 37 ARIZ. L. REv. 825, 828 (1995) ("The nineteenth century origins of physician licensure have been thoroughly studied, and a variety of theories have emerged as to why licensure was in fact adopted.")

35. See, e.g., Christy Ford Chapin, Ensuring America's Health-The Public Creation of the Corporate Health Care System 14-15 (2015).

36. See generally Daniel Carpenter \& David A. Moss, Introduction to Preventing Regulatory Capture: Special Interest Influence and How to Limit It (Daniel Carpenter \& David A. Moss eds., 2014).

37. Id at 12 .

38. See, e.g., Hal Varian, Microeconomic Analysis 382-84 (2010) (explaining how marginal costs can exceed average costs).

39. See, e.g., Charles H. Baron, Licensure of Health Care Professionals: The Consumer's Case for Abolition, 9 AM.J.L. \& MED. 335, 341 (1983) ("Licensure, however, has not produced the desired gains in the quality of health care, in large measure because the profession itself controls the licensure mechanism."); Aaron Edlin \& Rebecca Haw, Cartels by Another Name: Should

Licensed Occupations Face Antitrust Scrutiny?, 162 U. PA. L. REv. 1093, 1116 (2014) ("The economic research on quality of service as a function of licensing paints a murky picture."). 
true that a large majority of empirical studies find that licensing restrictions do not improve quality, these studies have of necessity focused on incremental changes in licensing restrictions, rather than comparing licensed professionals to comparable unlicensed professionals. ${ }^{40}$ Furthermore, by necessity, these studies have tended to focus on evaluating licensing requirements that vary across states, rather than those that have been adopted by all fifty states (e.g., the requirement that physicians attend medical school). One might reasonably assume that the former requirements are less likely to have impacts on quality than the latter.

The quality impacts of these policies are certainly relevant to decisions about licensure rules that policymakers are commonly faced with today. However, it is important to acknowledge the limitations of this literaturewhich is less informative with regard to licensing requirements that have been universally adopted by all fifty states and therefore cannot be easily studied - as well as the impacts of licensing laws as a whole.

The few studies that focus on the initial adoption of licensing laws find that licensing has in fact led to quality improvements. For example, one study examines the adoption of licensing requirements in the late 19th and early 20th centuries and finds evidence that licensing restrictions raised the quality of physicians and lowered mortality in specific areas where physician quality was most likely to have mattered at that time. ${ }^{41}$ Another recent study finds that licensing laws for midwives reduced maternal and infant mortality. 42

The discrepancy between the research focusing on contemporary licensing restrictions and the research focusing on earlier requirements may be attributable to the fact that the most valuable licensing rules - in the protection of health and safety - were likely to be implemented first. Professions for which there was a stronger health or safety justification, such as medicine, were among the first to be licensed and are now universally licensed. Within professions, the most valuable rules were likely adopted early. Subsequent "ratcheting-up" of licensing requirements may have added less value. ${ }^{43}$ Studies that focus on the initial adoption of licensing laws may cap-

40. See WH REPORT, supra note 24, at 60 ("[M] ost of the empirical evidence on licensing comes from looking at very specific examples. While the aforementioned studies indicate that occupational licensing does not guarantee quality improvements, they likewise do not indicate that all licensing frameworks fail to increase service quality.”).

41. See Law \& Kim, supra note 1 , at 748 .

42. See Mark Anderson et al., The Effect of Occupational Licensing on Consumer Welfare: Early Midwifery Lawes and Maternal Mortality (Nat'l Bureau of Econ. Research, Working Paper No. 22456, 2016).

43. See, e.g., Suyoun Han \& Morris M. Kleiner, Analyzing the Influence of Occupational Licensing Duration and Grandfathering on Labor Market Outcomes 27 (Nat'l Bureau of Econ. Research, Working Paper No. 22810, 2017) (noting that adding these licensing requirements results in fewer practitioners working longer hours). 
ture the effects of the most useful licensing rules, but those focused on more incremental changes in licensing restrictions would not.

In sum, contrary to some deregulatory proponents, we do not believe there is sufficient evidence to conclude that abolishing licensing would have no impact on quality (or, still further, improve quality). ${ }^{44}$ Rather, the available evidence suggests a more limited conclusion: that many contemporary licensing restrictions do not improve quality, particularly some restrictions that vary across jurisdictions. ${ }^{45}$ However, the literature suggests that some licensing requirements likely lead to quality improvements. Carefully distinguishing those requirements from unnecessary requirements is an important objective for public policy.

\section{B. The Harms of Licensing in Traditionally Licensed Fields}

From reading many of the popular accounts of licensing, one might be forgiven for assuming that the vast majority of licensed workers hold relatively uncommon low-wage jobs. ${ }^{46}$ Prominent media outlets such as The New York Times and The Wall Street Fournal have featured stories emphasizing the wide array of professions now subject to licensing requirements, including horse masseurs, shampooers, egg handlers, and upholstery repairers. ${ }^{47}$ The disproportionate attention paid to licensing requirements in these professions is in part attributable to the steady increase in licensing of occupations that historically were not previously licensed. ${ }^{48}$

Critics of licensure also tend to focus on these professions because they make the strongest rhetorical argument that licensing is not necessary to improve quality. Proponents of the public choice account often tend to fo-

44. See, e.g., Milton Friedman, Capitalism and Freedom 158 (1962) ("I am myself persuaded that licensure has reduced both the quantity and quality of medical practice.").

45. See WH REPORT, supra note 24, at 13.

46. See, e.g., Larkin, supra note 2, at 216-19 (listing a number of professions that do not appear to fit the rationale for licensing); Morris M. Kleiner, Why License a Florist, N.Y. Times (May 28, 2014), https://www.nytimes.com/2014/05/29/opinion/why-license-aflorist.html.

47. See Patricia Cohen, Moving to Arizona Soon? You Might Need a License, N.Y. Times (June 17, 2016), https://www.nytimes.com/2016/06/18/business/economy/job-licenses.html; Josh Zumbrun, Occupational Licenses May Be Bad for the Economy, But Good for Workers Who Have Them, WALL StreET J. (Apr. 18, 2016, 1:13 PM), https://blogs.wsj.com/economics/2016/04/18/occupational-licenses-may-be-bad-for-theeconomy-but-good-for-workers-who-have-them/; see also Jacob Goldstein, Why It's Illegal To Braid Hair Without A License, NPR, Planet Money Blog (June 12, 2012, 9:06 AM), http://www.npr.org/sections/money/2012/06/21/154826233/why-its-illegal-to-braidhair-without-a-license (stating hair braiders are also required to be licensed).

48. See generally Kleiner \& Krueger, The Prevalence and Effects of Occupational Licensing, supra note 6, at 678; Kleiner \& Krueger, Analyzing the Extent and Influence of Occupational Licensing on the Labor Market, supra note 6, at S175-76. 
cus on licensing requirements for relatively small, lower-wage professions such as florists, since - to many people - it seems intuitively implausible that such professions pose enough of a threat to public safety to merit licensure. ${ }^{49}$ For the same reason, the predominance of public choice theory has led to less emphasis being placed on traditionally licensed professions such as medicine, for which the justification for licensing is stronger. ${ }^{50}$

This emphasis can obscure the fact that today, many licensed workers work in traditionally licensed fields such as health care, law, education, and business (Figure 1).51 Many of these professions are licensed by most or all states, and many of them earn higher incomes. Even some of the most fervent critics of licensing concede that the justification for licensing - though not necessarily the content of the licensing requirements or the current scope of practice - is stronger in fields like medicine, where unqualified practitioners can inflict substantial harm and where it is difficult for the public to evaluate a practitioner's quality. ${ }^{52}$

49. See, e.g., Larkin, supra note 2, at 219.

50. Arrow, supra note 21, at 967 ("It is the general social consensus, clearly, that the laissez-faire solution for medicine is intolerable.").

51. Bureau of Lab. Stats., Gurrent Population Survey, Certification and Licensing Status of the Employed by Occupation (2018). Some examples of licensed professions in healthcare, law, education, and business include physicians, pharmacists, dental hygienists, lawyers, teachers, personal financial advisors, tax preparers, real estate appraisers, and accountants.

52. See, e.g., FRIEDman, supra note 44, at 138 ("I agree that the case for licensure is stronger for medicine than for most other fields."); Shirley V. Svorny, Beyond Medical Licensure, Regulation, Spring 2015, at 26, 26 ("But when it comes to medical professionals, many of the staunchest critics of licensing back off."”). 


\section{Figure 1}

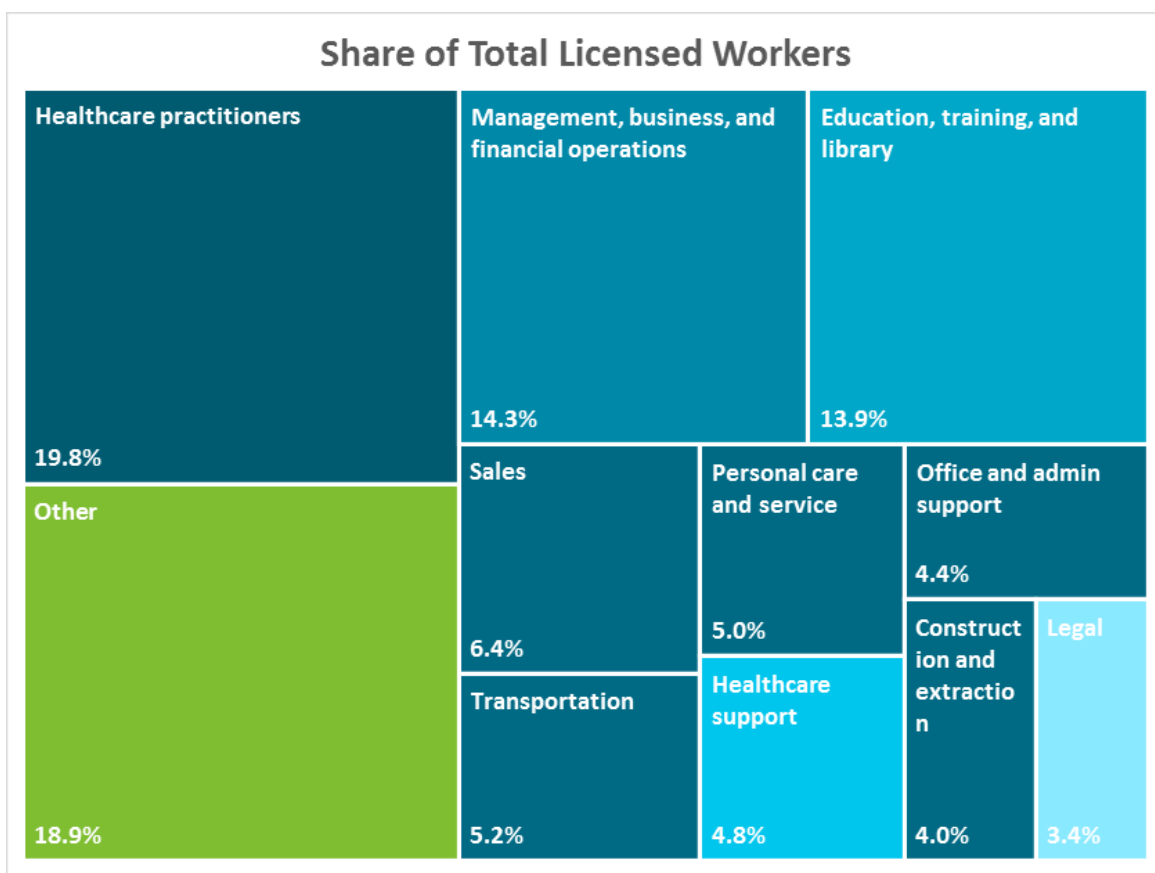

Source: Bureau of Labor Statistics 2018 and authors' calculations.

This emphasis is arguably misplaced, however, since licensing regimes in traditionally licensed fields such as medicine and law have some of the most harmful consequences for workers and consumers. Although licensing for most health care providers is widely viewed as necessary to ensure quality and to protect public safety, several features of this system restrict access to health care without resulting in appreciable quality improvements. ${ }^{53}$ For instance, so-called "scope-of-practice" restrictions prevent health care providers - such as nurse practitioners or dental hygienists - from offering services to the full extent of their competency. ${ }^{54}$ State-specific licensing re-

53. See Gabriel Scheffler, Unlocking Access to Health Care: A Federalist Approach to Reforming Occupational Licensing, 29 HEALTH MATRIX (forthcoming 2019) (outlining specific features of the licensing system for health care providers that limit access to health care without ensuring quality, and proposing a federalist approach to reform).

54. See, e.g., Leonard J. Finocchio et al., Pew Health Profs. Comm'n, Reforming Health Care Workforce Regulation: Policy Considerations for the 21st Century (1995); Inst. of Med., The Future of Nursing: Leading Change, Advancing Health (2011); E. Kathleen Adams \& Sara Markowitz, Improving Efficiency in the Health-Care System: Removing Anticompetitive Barriers for Advanced Practice Registered Nurses and Physician Assistants, Hamilton Project (June 2018), http://www.hamiltonproject.org/papers/removing_anticompetitive_barriers_for_advanced _practice_registered_nurses_a. 
quirements obstruct the adoption of telehealth by requiring health care providers to be separately licensed in each state that their patients are located, or by requiring face-to-face consultations..$^{55}$ In addition, licensing requirements deter foreign-trained providers from practicing in the United States by requiring them to complete costly and often duplicative training and testing. ${ }^{.5}$

Similarly, the licensure regime for legal practitioners has contributed to a system in which a staggering number of people are unable to afford legal representation, even when they are facing serious consequences, such as eviction, foreclosure, or imprisonment. ${ }^{57}$ For instance, in New York State in $2010,98 \%$ of tenants in eviction cases and $95 \%$ of parents in child support cases appeared in court without an attorney. ${ }^{58}$ Gillian Hadfield and Deborah Rhode write that "one major contributing factor" to this lack of access is that the market for legal services is "among the most, if not the most, intrusively regulated in the modern economy." 59 Hadfield and Rhode observe, for example, that only those who have obtained a Juris Doctor (J.D.), passed the bar exam, and hold a valid license may provide paid legal assistance, and that "[1] egal services must be provided by a law firm that is owned, managed, and financed exclusively by lawyers."60 While the current licensing regime may raise the quality of legal services for those who are able to obtain them, it likely causes others to go without legal services altogether.

\section{The Potential for Improving - Not Abolishing - Licensing}

The public choice account - if taken at face value - implies that abolish-

55. See, e.g., Diane E. Hoffman \& Virginia Rowthorn, Legal Impediments to the Diffusion of Telemedicine, 14 J. Health Care L. \& POL'Y 1, 8 (2011) ("State laws regarding physician licensure present the greatest challenge to the interstate practice of telemedicine.”).

56. See, e.g., Governor's Advisory Council For Refugees \& Immigrants Task Force on Immigrant Healthcare Prof'ls in Mass., Rx For Strengthening Massachusetts' Economy and Healthcare System (2014).

57. See Gillian K. Hadfield, Innovating to Improve Access: Changing the Way Courts Regulate Legal Markets, 143 Daedalus 83, 83-84 (2014).

58. Id.; see also Task Force to Expand Access to Givil Legal Services in New York, Report to the Chief Judge of the State of New York 1 (2010), http://ww2.nycourts.gov/sites/default/files/document/files/2018-04/CLS-

TaskForceREPORT.pdf.

59. Gillian K. Hadfield \& Deborah L. Rhode, How to Regulate Legal Services to Promote Access, Innovation, and the Quality of Laweyering, 67 Hastings L.J. 1191, 1194 (2015). But see Frank Pasquale, The Real Barriers to Access to Justice, PrawfsBlawg (Mar. 5, 2018), https://prawfsblawg.blogs.com/prawfsblawg/2018/03/legal-eds-futures-nol.html (attributing lack of access to legal representation to other factors, such as the underfunding of public defenders).

60. Hadfield \& Rhode, supra note 59, at 1194. 
ing licensing altogether is the ideal way to reform licensing, even when evidence supports less-radical reforms. If licensing mainly exists to enhance practitioners' market power, and if there is no legitimate public interest rationale, then why not just get rid of licensing altogether?61

Yet many of the costs of licensing appear to depend not on licensing per se, but on how specific licensing requirements are structured. For example, Janna Johnson and Morris Kleiner find that workers in occupations that have state-specific licensing exams are less likely to move across states than workers in other occupations, but workers in occupations with national licensing exams are no less likely to move than other workers. ${ }^{62}$ They also find that reciprocity agreements increase interstate mobility for lawyers. ${ }^{63}$

Similarly, a report by the National Employment Law Project found over 12,000 licensing restrictions that automatically disqualify individuals with any kind of felony, and more than 6,000 restrictions that disqualify individuals with a misdemeanor, regardless of whether there is reason to think they would pose a real threat to public health or safety. ${ }^{64}$

It is also important to consider the ways that licensing can limit innovation, particularly when licensing rules specify the ways in which work tasks must be conducted. ${ }^{65}$ Often these limitations are not intended by policymakers who introduce and formulate initial licensing requirements. Furthermore, although the requirements may be in line with the prevailing work standards at the time, as time passes, changing technology or other advances (e.g., the possibility of telehealth) may render the original regulation more confining. ${ }^{66}$

61. See CARPenter \& Moss, supra note 36, at 10 (“[A]rguments stipulating capture often ... move quickly from 'is' to 'ought,' and they are especially likely to recommend deregulation.").

62. Janna E. Johnson \& Morris M. Kleiner, Is OGGupational Licensing a BARRIER to INTERSTATE Migration 2 (2017).

63. Id.

64. Michelle Natividad Rodriguez \& Beth Avery, Nat'l Emp't Law Project, Unlicensed \& Untapped: REMOVing BarRiers to State OGGupational LicENSES FOR PeOple with Records 1, 10 (2016). However, it is important to note that these restrictions may benefit some workers who do not have criminal records. See Peter Q. Blair \& Bobby W. Chung, Occupational Licensing Reduces Racial and Gender Wage Gaps: Evidence from the Survey of Income and Program Participation 2-3 (Human Capital Econ. Opportunity Global Working Grp., Working Paper No. 2017-50 2017).

65. See, e.g., WH REPORT, supra note 24, at 45 (describing how the "the 'corporate practice of law' doctrine ... has been applied to online legal document and information companies seeking to provide online legal assistance or other innovative products.").

66. See, e.g., Daniel J. Gilman, Physician Licensure and Telemedicine: Some Competitive Issues Raised by the Prospect of Practicing Globally While Regulating Locally, 14 J. Health Care L. \& POL'y 87, 89 (2011) ("[T] elemedicine promises in various ways to reduce the costs and extend the reach of many health care services, but the advantages of remote and networked expertise may be poorly accommodated by licensing schemes that were developed to regu- 
Many of the harms of licensing are therefore not intrinsic to licensing itself, and some harms can be alleviated without eliminating licensing altogether. Reforms aimed at such harms may be complementary to delicensure efforts, as they address a different (and wider) range of occupations than it would be appropriate to delicense. The Obama Administration's 2015 report provided a number of best practices toward that end, including promoting the appointment of public representatives to licensing boards, harmonizing licensing requirements to the maximum extent possible across states, and limiting entry requirements to those that specifically address legitimate public health and safety concerns. ${ }^{67}$ Changes in how a profession is licensed - not just whether it is licensed - can result in tangible improvements in the lives of workers and consumers. ${ }^{6}$

\section{CONCLUSION}

In sum, the standard public choice narrative about occupational licensing is simultaneously overinclusive and underinclusive. On one hand, it is overinclusive as it suggests that licensing laws are rarely justified, even in the face of plausible alternative explanatory accounts. If policymakers and judges were to take this narrative at face value, they might strike down many licensing laws that benefit the public. Of course, there is a strong case for subjecting licensing laws to greater scrutiny, and there are professions for which the costs of licensure clearly outweigh the benefits. Yet in other cases - perhaps in many cases - the cost-benefit calculus will be less clear.

At the same time, however, the standard public choice narrative is underinclusive as it tends to focus less on dominant professional organizations, such as physicians and lawyers, and more on smaller, lower-wage professions. This is unfortunate, since the former licensing regimes have particularly detrimental consequences for workers and consumers. In addition, the public choice narrative is underinclusive because it has little to say about professions for which there are credible public safety risks of unregulated activity. We argue that there is a strong basis for licensure reform in these professions that, while less radical than complete deregulation, would nonetheless enhance labor market access and benefit consumers.

Judges in particular would do well to keep these critiques in mind. We believe that public officials and government agencies are better equipped than courts to implement the kind of nuanced and multi-faceted reforms that are necessary, and thus that the current constitutional challenges to li-

\footnotetext{
late local medical practices — practices historically dominated by face-to-face encounters between a physician and her patient.").

67. WH REPORT, supra note 24 , at 43.

68. Id. at 43-55 (explaining the benefits of these best practices, such as improved labor market entry and interstate mobility).
} 
censing regimes are unwise (to say nothing of their broader effects for regulation more generally). Of course, reforming licensing through the political process is difficult, but the federal government has taken several initial steps toward changing licensing requirements for health care providers, which provides reason for cautious optimism. ${ }^{69}$ Regardless, policymakers and judges would do well to draw on the public choice account of licensing without adopting it uncritically.

69. See Scheffler, supra note 53. 